\title{
Characteristics of Gas Exchange in Three Domesticated Anemone Species
}

\author{
Feihu Liu ${ }^{1 *}$, Fei Li ${ }^{1}$, Xueni Liang ${ }^{2}$ \\ ${ }^{1}$ Faculty of Life Science, Yunnan University, Kunming, China; ${ }^{2}$ College of Adults and Professional Education, Yunnan University, \\ Kunming, China. \\ Email: ${ }^{*}$ plantbreed2004@yahoo.com.cn
}

Received August $9^{\text {th }}, 2010$; revised August 27 ${ }^{\text {th }}, 2010$; accepted August $31^{\text {st }}, 2010$

\begin{abstract}
Seeds of three Anemone species were collected from the suburban areas of Kunming and planted in a nursery for three and a half years at Kunming, Yunnan Province, China. Leaf gas exchange measurement indicated that these species had similar one-peak diurnal trends of net photosynthetic rate $\left(P_{N}\right)$, although A. rivularis had lower transpiration rate $(T R)$, stomatal conductance $\left(g_{s}\right)$ and intercellular $\mathrm{CO}_{2}$ concentration $\left(C_{i}\right)$, and higher stomatal limit in the afternoon. Species differences in response of $P_{N}$ to photosynthetically active radiation (PAR) were observed, especially under strong light. A. rivularis had the highest $P_{N}$ and $C_{i}$ under strong light which corresponded with its highest $g_{s}$ and TR. A. rivularis had the highest light saturation point (LSP) $\left(1000 \mu \mathrm{mol} \mathrm{m} \mathrm{m}^{-2}\right)$ and light compensation point $(L C P)(69 \mu \mathrm{mol}$ $\left.\mathrm{m}^{-2} \mathrm{~s}^{-1}\right)$, while A. hupehensis var. japonica had the lowest LSP $\left(800 \mu \mathrm{mol} \mathrm{m} \mathrm{m}^{-1}\right)$ and a lower LCP $\left(53 \mu \mathrm{mol} \mathrm{m} \mathrm{s}^{-2} \mathrm{~s}^{-1}\right)$. But the three species responded similarly to the change of $\mathrm{CO}_{2}$ concentration in the air from 0 to $350 \mu \mathrm{mol}\left(\mathrm{CO}_{2}\right) \mathrm{mol}^{-1}$, and their observed $\mathrm{CO}_{2}$ compensation point showed little difference (47, 53 and $\left.56 \mu \mathrm{mol}\left(\mathrm{CO}_{2}\right) \mathrm{mol}^{-1}\right)$. Moreover, A. rivularis had the highest apparent quantum yield (0.032), carboxylation efficiency $(0.049), P_{N}\left(11.68 \mu \mathrm{mol}\left(\mathrm{CO}_{2}\right) \mathrm{m}^{-2} \mathrm{~s}^{-1}\right)$ and TR $\left(5.36 \mathrm{mmol}\left(\mathrm{H}_{2} \mathrm{O}\right) \mathrm{m}^{-2} \mathrm{~s}^{-1}\right)$ based on the $P_{N}$-PAR response. The results implied that A. rivularis is able to grow well under higher radiation, while A. hupehensis var. japonica is the best one to grow under partial shade.
\end{abstract}

Keywords: $\mathrm{CO}_{2}$ Compensation Point, Gas Exchange, Light Compensation Point, Light Saturation Point

\section{Introduction}

Anemone is a newly developed species for cut flowers that is also used as a potted plant. Many commercial Anemone varieties have been released in other countries [1]. Anemone is an important genera (25 species, 4 subspecies, and 9 varieties) in Yunnan province, China [2]. Investigations have been reported on taxonomy, cytology and pollen morphology of Anemones [3, 4] and breeding studies were carried out by Hoot [5], Jacob [6] and Lindell [7]. However, photosynthesis has not been documented for the genus.

Many studies are being done on development and utilization of wild flower species for ornamental purpose, of which cultivation of the wild species is one of the important challenges [1]. Three wild Anemone species, collected from Yunnan Province, were successfully cultured in a suburban plant nursery at Kunming, but they showed different responses to the light environment. This was reasonable in view of their in situ growth environment, and suggested the importance of controlling light intensity in artificial culture of these wild plants. Consequently, these Anemone species were presumed to have their own peculiarities in photosynthesis. This paper aimed at studying the photosynthetic characteristics of Anemone species and their photosynthetic responses to the important components of the environment, providing knowledge for controlling light conditions in the cultivation of Anemone species.

\section{Materials and Methods}

\subsection{Plants and Cultivation}

Three Anemone representative species were selected according to the distribution, leaf and plant form, and growth habit. Seeds were collected from the suburban areas of Kunming, Yunnan Province, China. A. vitifolia Buch.Han. Ex DC. (growing on a stony hillside at $2200 \mathrm{~m}$ a.s.l), A. rivularis Buch.-Han. Ex DC. (growing on a grass hillside under sparse trees at $2230 \mathrm{~m}$ a.s.l.) and $A$. hupehensis Lemoine var. japonica (Thunb.) Bowles et Stearn (growing on a limestone wall at $2180 \mathrm{~m}$ a.s.l). Seedlings from 
seeds planted in a suburban nursery of light loam soil with satisfied drainage at Kunming in early spring of 2000 (random block design with three replicates, at density of $20 \times 40 \mathrm{~cm}$ in $3 \mathrm{~m}^{2}$ plots). The plants had grown under light shade of trees $(50 \%-100 \%$ of natural sunshine, varied along with the angle of incidence), for three and a half years at which time the tests were carried out.

Kunming $\left(25^{\circ} 01^{\prime} \mathrm{E}, 102^{\circ} 41^{\prime} \mathrm{N}, 1896 \mathrm{~m}\right.$ a.s.l) has a dry season from November through April and a wet season from May through October, with a yearly mean temperature of $14.9^{\circ} \mathrm{C}, \mathrm{RH}$ of $72 \%$, and an annual rainfall of $1011 \mathrm{~mm}$. The full natural sun radiation at the experimental site was recorded equivalent photosynthetically active radiation $1500-2000 \mu \mathrm{mol} \mathrm{m} \mathrm{m}^{-2} \mathrm{~s}^{-1}$ on cloud-free days throughout the growth season. The soil prior to the experiment contained $150.3 \mathrm{mg} \mathrm{kg}^{-1}$ hydrolysable nitrogen, $25.1 \mathrm{mg} \mathrm{kg}^{-1}$ available phosphorus, $250.3 \mathrm{mg} \mathrm{kg}^{-1}$ available potassium, $5 \%$ of organic matter and with a $\mathrm{pH} 7.45$.

The plants were watered if necessary to avoid water stress during the growing season and were fertilized twice a year before flowering, each time with $80 \mathrm{~kg} \mathrm{ha}^{-1}$ of urea $(46 \%$ of $\mathrm{N}), 100 \mathrm{~kg} \mathrm{ha}^{-1}$ of normal calcium superphosphate $\left(18 \%\right.$ of $\left.\mathrm{P}_{2} \mathrm{O}_{5}\right)$ and $65 \mathrm{~kg} \mathrm{ha}^{-1}$ of potassium sulfate $\left(50 \%\right.$ of $\left.\mathrm{K}_{2} \mathrm{O}\right)$. The plants showed normal growing, flowering, and fruit setting. The biomass was tested for the species by harvesting all the plots when photosynthesis measurement finished.

\subsection{Photosynthesis Measurements and Environmental Data}

In late July, 2003 during flower bud stage, net photosyn- thetic rate $\left(P_{\mathrm{N}}\right)$ (3 plants per species, the last fully expanded leaf per plant) in the three species was measured in the field by a portable gas-exchange analyzer (LI-6400, LICOR, Lincoln, NE, USA) (tested leaf area $6 \mathrm{~cm}^{2}$, air flow rate $400 \mu \mathrm{mol} \mathrm{s}^{-1}$, stomatal ratio 0.5 , a long tube was used to draw the inlet air far from the operator in order to minimize human impact on the $\mathrm{CO}_{2}$ levels). Stomatal conductance $\left(g_{\mathrm{s}}\right)$, intercellular $\mathrm{CO}_{2}$ concentration $\left(C_{\mathrm{i}}\right)$, transpiration rate (TR), air temperature $\left(T_{\mathrm{a}}\right)$, ambient $\mathrm{CO}_{2}$ concentration $\left(C_{\mathrm{a}}\right)$, relative air humidity $(\mathrm{RH})$ and photosynthetically active radiation (PAR) were also recorded.

Diurnal trend of $P_{\mathrm{N}}$ was analyzed at 1-hour intervals from 0700 to $1900 \mathrm{~h}$ on a cloud-free day. This was repeated on one subsequent cloud-free day. Leaf water use efficiency (LWUE) was calculated as $P_{\mathrm{N}} /$ TR [8], and stomatal limitation $\left(L_{\mathrm{s}}\right)$ as $\left(C_{\mathrm{a}}-C_{\mathrm{i}}\right) / C_{\mathrm{a}}$ [9]. The environmental conditions were recorded by the LI-6400 instrument as shown in Figures 1(a), (b). $C_{a}$ and RH did vary considerably from early morning to nightfall.

The response of photosynthesis to light intensity was measured. $P_{\mathrm{N}}$ was tested from $0830-1130 \mathrm{~h}$ on a cloudfree day respectively under PAR 2000, 1800, 1600, 1400, $1200,1000,800,600,400,200$, and $0 \mu \mathrm{mol} \mathrm{m}^{-2} \mathrm{~s}^{-1}$ (using 6400-02B light source) to set up a response of photosynthesis to light intensity, when $T_{\mathrm{a}}, \mathrm{RH}$, and $C_{\mathrm{a}}$ were 22.5-28 ${ }^{\circ} \mathrm{C}, 45-65 \%$, and $360-375 \mu \mathrm{mol}\left(\mathrm{CO}_{2}\right) \mathrm{mol}^{-1}$. On one subsequent cloud-free day from 0830-1030 h, $P_{\mathrm{N}}$ was tested respectively under PAR 800, 600, 400, 200, 80,40 , and $0 \mu \mathrm{mol} \mathrm{m} \mathrm{m}^{-2}$ to determine accurate light compensation points in different species, when $T_{\mathrm{a}}, \mathrm{RH}$, and $C_{\mathrm{a}}$ were $23-26.5^{\circ} \mathrm{C}, 50-65 \%$, and $365-375 \mu \mathrm{mol}$
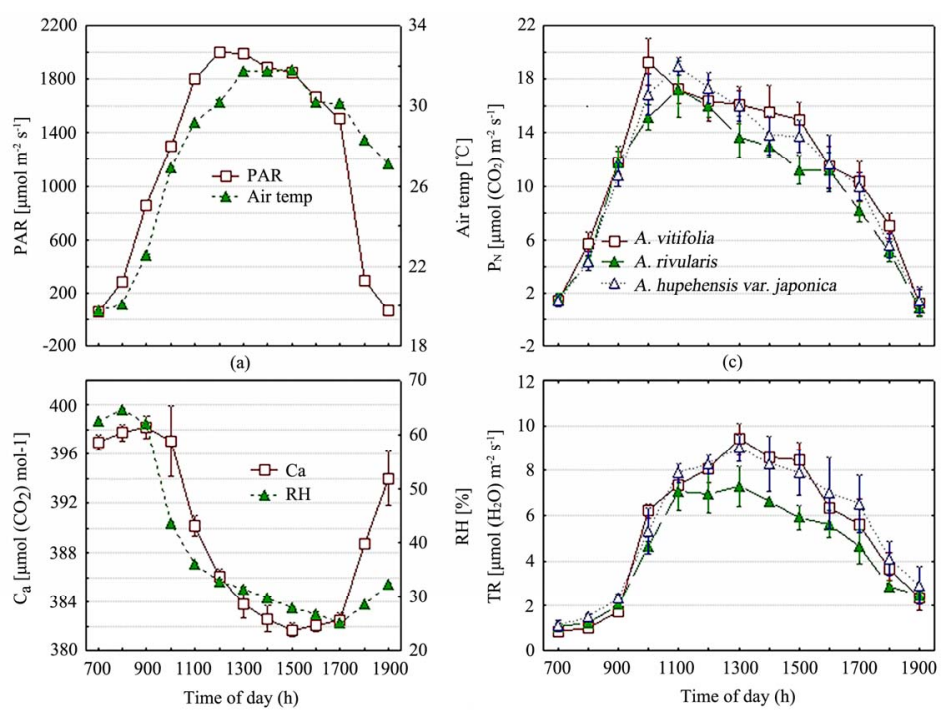

(d)

Figure 1. Diurnal trends of the photosynthetically active radiation (PAR), air temperature $\left(T_{\mathrm{a}}\right)$, ambient $\mathrm{CO}_{2}$ concentration $\left(C_{\mathrm{a}}\right)$, relative humidity $(\mathrm{RH})$, net photosynthetic rate $\left(P_{\mathrm{N}}\right)$ and transpiration rate $(\mathrm{TR})$ in the domesticated Anemone species. The symbols and the vertical bars in the figure were mean \pm standard deviation. 
$\left(\mathrm{CO}_{2}\right) \mathrm{mol}^{-1}$. Sample leaves were first exposed to the highest PAR. When a constant $P_{\mathrm{N}}$ was achieved PAR was lowered step by step to total darkness. At each step, a constant $P_{\mathrm{N}}$ was achieved prior to recording the data. The apparent quantum yield (AQY) was calculated as the initial slope of the regression $P_{\mathrm{N}}$ on PAR under conditions of PAR 0,40 and $80 \mu \mathrm{mol} \mathrm{m} \mathrm{s}^{-2}$ [10-12].

Light saturation points (LSP) were the turning point areas on the curves in Figure 3(a), while light compensation points (LCP) were derived from the linear correlation of $P_{\mathrm{N}}$ and PAR when PAR $\leq 80 \mu \mathrm{mol} \mathrm{m} \mathrm{m}^{-2}$ (Figure 4), here the constant dependent $X$ (PAR) was considered as LCP, i.e., the PAR value when $P_{\mathrm{N}}=$ zero. $\mathrm{CO}_{2}$ compensation points (CCP) was determined by the linear correlation between $P_{\mathrm{N}}$ and $C_{\mathrm{a}}$ when $C_{\mathrm{a}} \leq 100 \mu \mathrm{mol}\left(\mathrm{CO}_{2}\right) \mathrm{mol}^{-1}$ (Figure 5(a)), here the constant dependent $\mathrm{X}\left(\mathrm{CO}_{2}\right)$ was considered as CCP, i.e., the $\mathrm{CO}_{2}$ value when $P_{\mathrm{N}}=$ zero.

The response of photosynthesis to $\mathrm{CO}_{2}$ concentration was measured from $0900-1100 \mathrm{~h}$ on another cloud-free day, when $T_{\mathrm{a}}$ and $\mathrm{RH}$ were $24-27^{\circ} \mathrm{C}$ and $55-65 \%$. PAR was set at $1200 \mu \mathrm{mol} \mathrm{m} \mathrm{m}^{-2} \mathrm{~s}^{-1}$ based on the $P_{\mathrm{N}}$-PAR response (see Figure 3(a)), and $C_{\mathrm{a}}$ was set at 0, 50, 100, $150,200,250,300$, and $350 \mu \mathrm{mol}\left(\mathrm{CO}_{2}\right) \mathrm{mol}^{-1}$ by adjusting the instrument. The carboxylation efficiency (CE) was calculated as the initial slope of the regression $P_{\mathrm{N}}$ on $C_{\mathrm{i}}$ under conditions of $C_{\mathrm{a}} 0,50$ and $100 \mu \mathrm{mol}\left(\mathrm{CO}_{2}\right) \mathrm{mol}^{-1}$ $[9,13]$.

\subsection{Data Analysis}

$P_{\mathrm{N}}$ and TR values at the seven PAR settings i.e. 800, 1000,

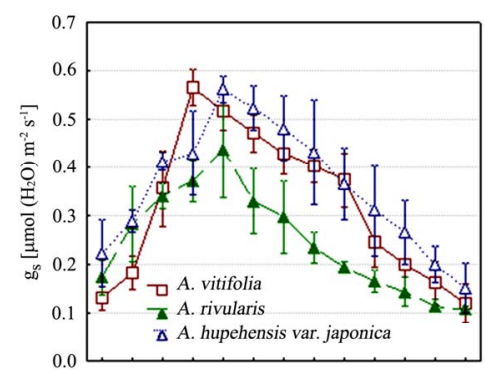

(a)

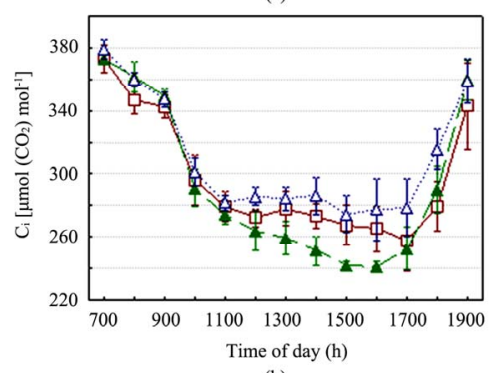

(b)
1200, 1400, 1600, 1800 and $2000 \mu \mathrm{mol} \mathrm{m}^{-2} \mathrm{~s}^{-1}$ were used for comparing $P_{\mathrm{N}}$ and TR among species. Specific difference was determined by LSD test (Fisher) at $\alpha=0.05$. Post hoc comparisons for the data in Table 1 and all diagrams were carried out using Statistica 5.0 (StatSoft Inc. (1995) STATISTICA). The vertical bars in the figures were means \pm standard deviations (SD).

\section{Results}

\subsection{Diurnal Patterns of $\boldsymbol{P}_{\mathrm{N}}$ and the Related Pa- rameters}

The three species had similar one-peak diurnal trends of $P_{\mathrm{N}}$ showing an asymmetric parabola-like curve (Figure 1(c)). A. vitifolia had a maximum $P_{\mathrm{N}}$ at $1000 \mathrm{~h}$, the other two at $1100 \mathrm{~h}$. At 1000, 1300-1500 and 1700-1800 h, A. rivularis had lower $P_{\mathrm{N}}$ values than $A$. vitifolia. TR showed the same trend peaking at $1300 \mathrm{~h}$ (Figure 1(d)), but $A$. rivularis had lower TR than the other two from 1200-1700 h.

The diurnal trends of $g_{\mathrm{s}}$ in the three species were similar, but species differences could be seen from the height of peaks and curves, as well as the timing of peak value (Figure 2(a)). $C_{\mathrm{i}}$ decreased up to $1000 \mathrm{~h}$ and increased after $1700 \mathrm{~h}$ (Figure 2(b)), showing little change from 1000 to $1700 \mathrm{~h}$ at about $280 \mu \mathrm{mol}\left(\mathrm{CO}_{2}\right) \mathrm{mol}^{-1}$, with $A$. rivularis being exceptionally low, the result from the lower values of $g_{\mathrm{s}}$ (Figure 2(a)).

LWUE peaked at $0900 \mathrm{~h}$, decreasing from $0900 \mathrm{~h}$ to $1100 \mathrm{~h}$ due to TR increase (Figure 1(d)), then remaining
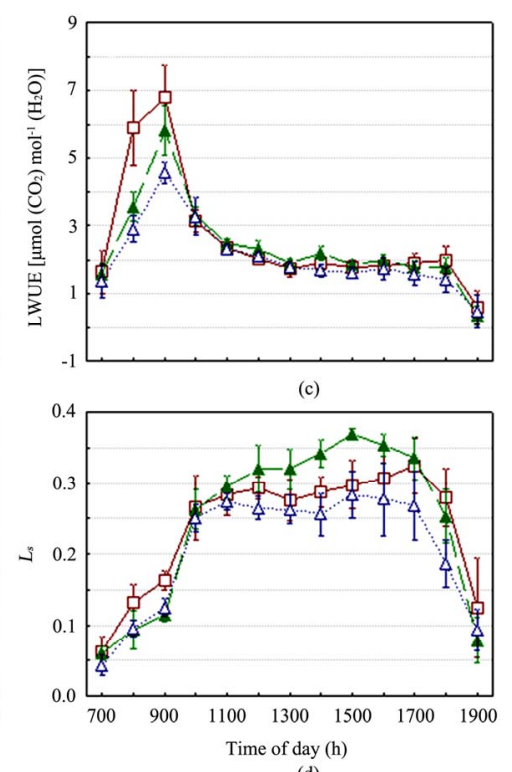

(d)

Figure 2. Diurnal trends of the stomatal conductance $\left(\mathrm{g}_{\mathrm{s}}\right)$, intercellular $\mathrm{CO}_{2}$ concentration $\left(C_{\mathrm{i}}\right)$, leaf water use efficiency $\left(\mathrm{LWUE},=P_{\mathrm{N}} / \mathrm{TR}\right)$ and stomatal limitation $\left(L_{\mathrm{s}},=\left(C_{\mathrm{a}}-C_{\mathrm{i}}\right) / C_{\mathrm{a}}\right)$ in the domesticated Anemone species. The symbols and the vertical bars in the figure were mean \pm standard deviation. 


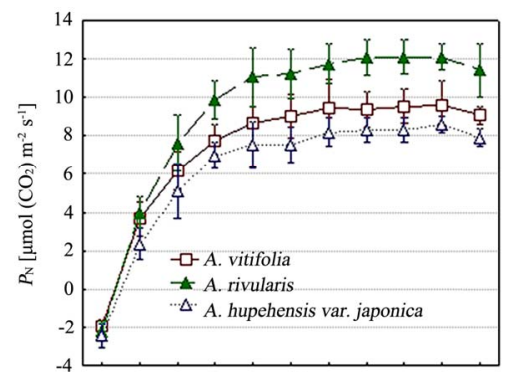

(a)

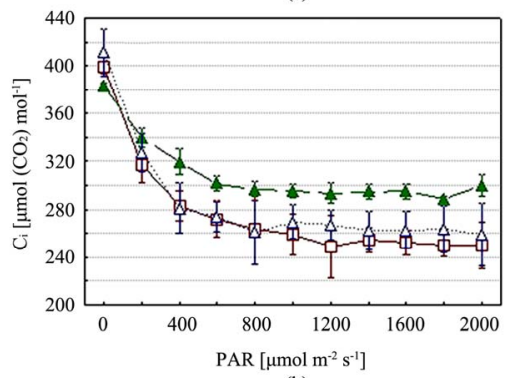

(b)
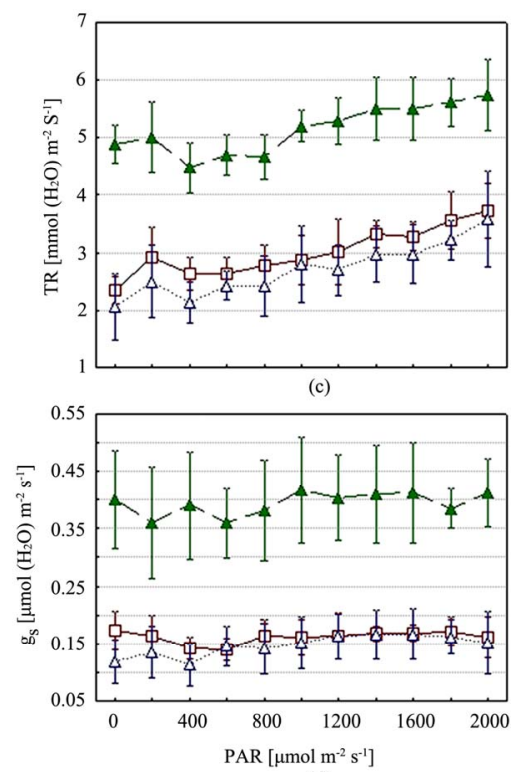

(d)

Figure 3. Responses of the net photosynthetic rate $\left(P_{\mathrm{N}}\right)$, intercellular $\mathrm{CO}_{2}$ concentration $\left(C_{\mathrm{i}}\right)$, transpiration rate (TR) and stomatal conductance $\left(g_{s}\right)$ to photosynthetically active radiation (PAR) in the domesticated Anemone species. The symbols and the vertical bars in the figure were mean \pm standard deviation.

constant until $1800 \mathrm{~h}$ (Figure 2(c)). $L_{\mathrm{s}}$ showed diurnal variations and all the species maintained high $L_{\mathrm{s}}$ values from $1000 \mathrm{~h}$ to $1700 \mathrm{~h}$ (Figure 2(d)), but $A$. rivularis had the highest values of $L_{\mathrm{s}}$ from $1200-1600 \mathrm{~h}$.

\subsection{Response of Photosynthesis to Light Intensity}

$P_{\mathrm{N}}$ responses to PAR of the considered species showed significant differences under the light intensity of 400 through to $2000 \mu \mathrm{mol} \mathrm{m}{ }^{-2} \mathrm{~s}^{-1}$. Under this condition, $A$. rivularis had the highest $P_{\mathrm{N}}$, and $A$. hupehensis var. japonica had the lowest, showing their difference in sensitivity to light intensity (Figure 3(a)). $P_{\mathrm{N}}$ increased rapidly when PAR increased from zero to 600 or $800 \mu \mathrm{mol} \mathrm{m}$ $\mathrm{s}^{-1}$, although light depression of photosynthesis was not observed within the short time (0900-1100 h) when PAR did not exceed $1800 \mu \mathrm{mol} \mathrm{m} \mathrm{m}^{-2}$. LSPs were $1000 \mu \mathrm{mol}$ $\mathrm{m}^{-2} \mathrm{~s}^{-1}$ for A. rivularis and A. vitifolia, and $800 \mu \mathrm{mol} \mathrm{m}{ }^{-2}$ $\mathrm{s}^{-1}$ for A. hupehensis var. japonica (Figure 3(a)). LCPs of A. vitifolia, A. hupehensis var. japonica and A. rivularis were $47 \pm 1.2(\mathrm{SD}), 53 \pm 1.4$ and $69 \pm 1.6 \mu \mathrm{mol} \mathrm{m}^{-2}$ $\mathrm{s}^{-1}$ (Figure 4).

$C_{\mathrm{i}}$ responded to light intensity reversal to $P_{\mathrm{N}}$ (Figure 3(b)) and reached 380-410 $\mu \mathrm{mol}\left(\mathrm{CO}_{2}\right) \mathrm{mol}^{-1}$ when the leaf was put in dark $(\mathrm{PAR}=0)$. A. rivularis had higher $C_{\mathrm{i}}$ values than the other two under light intensity of

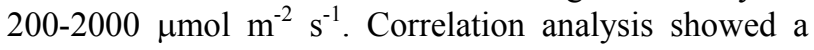
significantly negative correlation between $P_{\mathrm{N}}$ and $C_{\mathrm{i}}(\mathrm{r}=$ $-0.93^{*}$, data not shown). Moreover, Anemones showed a stable TR that was influenced little by the increasing PAR (Figure 3(c)), and A. rivullaris had the highest TR values that corresponded with $g_{\mathrm{s}}$ (Figure 3(d)).

\subsection{Response of Photosynthesis to $\mathrm{CO}_{2}$ Concentration}

To estimate CCP and CE, $P_{\mathrm{N}}$ responses of the Anemone species were measured under a range of $C_{a}$ from 0 to 350 $\mu \mathrm{mol}\left(\mathrm{CO}_{2}\right) \mathrm{mol}^{-1}$. $P_{\mathrm{N}}$ increased when $C_{\mathrm{a}}$ increased from

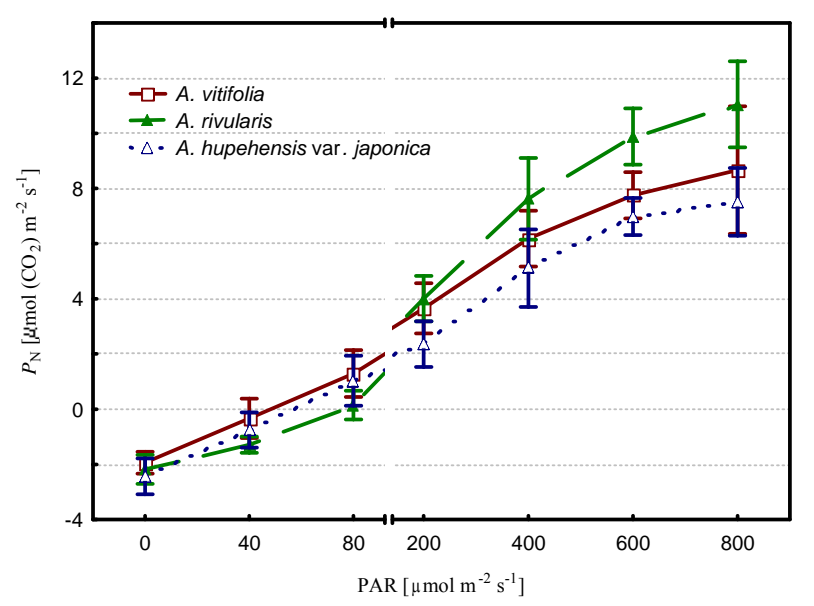

Figure 4. Photosynthetic rate $\left(P_{N}\right)$ of the Anemone species under low photosynthetically active radiation (PAR) showing the light compensation point. The symbols and the vertical bars in the figure were mean \pm standard deviation. 

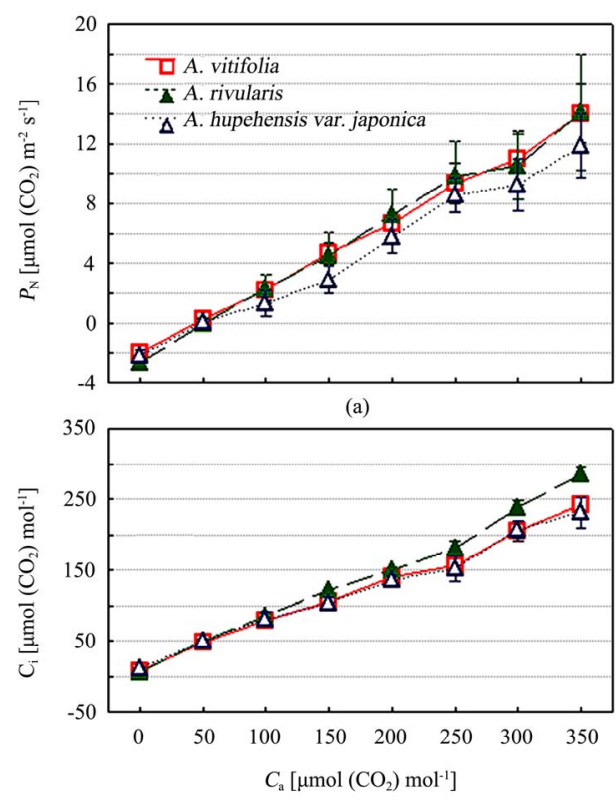

(b)

Figure 5. Responses of the net photosynthetic rate $\left(P_{\mathrm{N}}\right)$ and intercellular $\mathrm{CO}_{2}$ concentration $\left(C_{\mathrm{i}}\right)$ to ambient $\mathrm{CO}_{2}$ concentration $\left(C_{\mathrm{a}}\right)$ in the domesticated Anemone species. The symbols and the vertical bars in the figure were mean \pm standard deviation.

0 to $350 \mu \mathrm{mol}\left(\mathrm{CO}_{2}\right) \mathrm{mol}^{-1}$, showing insignificant differences among the considered species (Figure 5(a)). $C_{\mathrm{i}}$ showed same response to the change of $C_{\mathrm{a}}$ (Figure 5(b)). $\mathrm{CCP}$ was $47 \pm 1.0$ (SD) $\mu \mathrm{mol}\left(\mathrm{CO}_{2}\right) \mathrm{mol}^{-1}$ for $A$. vitifolia, $53 \pm 1.1$ for $A$. rivularis and $56 \pm 1.4$ for $A$. hupehensis var. japonica (Figure 5(a)).

\subsection{Differences in $P_{N}, T R, C E, A Q Y$ and Biomass}

$P_{\mathrm{N}}$ and TR were compared according to the data of $P_{\mathrm{N}} /$

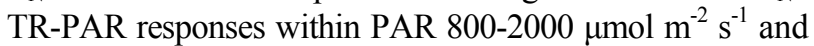
showed significant specific difference (Table 1). A. rivularis had the highest $P_{\mathrm{N}}$ and TR, while $A$. hupehensis var. japonica had the lowest. The specific difference was observed in biomass that showed a close correlation with
$P_{\mathrm{N}}\left(\mathrm{r}=0.991^{*}\right.$, Table 1).

CE varied from 0.036 to 0.049 among the species with A. rivularis having the highest $\mathrm{CE}$. The specific difference in CE showed a close correlation with $P_{\mathrm{N}}$ values (r $=0.999^{*}$, Table 1). AQY was in the range 0.023 to 0.032 ; A. rivularis again had the highest value. AQY was also closely associated with $P_{\mathrm{N}}$ values $\left(\mathrm{r}=0.999^{*}\right.$, Table 1).

\section{Discussion}

\subsection{Diurnal Trend of Photosynthetic Rate}

In this experiment, the major environmental factors, PAR, $T_{\mathrm{a}}$ and air RH changed remarkably during the day as shown in Figures 1(a), (b). This situation is normal at our experimental site and is the driver of $P_{\mathrm{N}}$ daily change. No increase of $P_{\mathrm{N}}$ was observed in the afternoon while a midday depression in photosynthesis was found in Anemone species collected from the alpine region in suburban areas of Kunming (1896 $\mathrm{m}$ a.s.1.). $P_{\mathrm{N}}$ increased before 1000 or $1100 \mathrm{~h}$ and decreased from 1000 or 1100 $\mathrm{h}$ (dependent on species) onwards. The increase of $P_{\mathrm{N}}$ in the morning was driven by the increase of PAR and $g_{\mathrm{s}}$ (Figures 1(a), (c); Figure 2(a)), and decrease of $P_{\mathrm{N}}$ from the late morning to the afternoon was caused by the decrease of $g_{\mathrm{s}}$ (Figure 1(c); Figure 2(a)). A close link between $P_{\mathrm{N}}$ and $g_{\mathrm{s}}$ and/or PAR (only in the morning) was observed in the investigation of the diurnal trends of photosynthetic rate for Ginkgo biloba, Paspalum notatum, and Enkleia malaccensis [14-16]. Whereas $g_{\mathrm{s}}$ decrease in this experiment resulted from the integrative action of adverse ecological factors such as the rise of $T_{\mathrm{a}}\left(>30^{\circ} \mathrm{C}\right)$, decrease of air $\mathrm{RH}(<35 \%)$ and $C_{\mathrm{a}}\left(<386 \mu \mathrm{mol}\left(\mathrm{CO}_{2}\right) \mathrm{mol}^{-1}\right)$, and strong light $\left(>1500 \mu \mathrm{mol} \mathrm{m}^{-2} \mathrm{~s}^{-1}\right)$ (Figures 1(a), (b)). A strong light of no more than $1800 \mu \mathrm{mol} \mathrm{m} \mathrm{m}^{-2} \mathrm{~s}^{-1}$ did not depress the photosynthesis of the Anemones in the field (Figure 3(a)). This may reflect the intrinsic adaptation of the Anemone species to the mild ecological environments in their native habitats of moderate $T_{\mathrm{a}}$, higher air RH but strong light. The decrease of $g_{\mathrm{s}}$ from 1000 or $1100 \mathrm{~h}$ onwards and the decrease of TR in the afternoon were caused by the increase of stomatal limitation $\left(L_{\mathrm{s}}\right)$

Table 1. Carboxylation efficiency (CE), apparent quantum yield (AQY), Photosynthetic rate $\left(P_{\mathrm{N}}\right)$, transpiration rate (TR) and biomass of the Anemone species.

\begin{tabular}{cccccc}
\hline Taxon & CE & AQY & $P_{\mathrm{N}}$ & TR & Biomass $\left(\mathrm{kg} \mathrm{m}^{-2}\right)$ \\
\hline A. rivularis & $0.0491 \pm 0.0014^{\mathrm{a}}$ & $0.0317 \pm 0.0005^{\mathrm{a}}$ & $11.68 \pm 0.448^{\mathrm{a}}$ & $5.36 \pm 0.354^{\mathrm{a}}$ & $1.02 \pm 0.055^{\mathrm{a}}$ \\
A. vitifolia & $0.0417 \pm 0.0011^{\mathrm{b}}$ & $0.0275 \pm 0.0007^{\mathrm{b}}$ & $9.25 \pm 0.346^{\mathrm{b}}$ & $3.22 \pm 0.351^{\mathrm{b}}$ & $0.83 \pm 0.071^{\mathrm{b}}$ \\
A. hupehensis var. japonica & $0.0355 \pm 0.0013^{\mathrm{c}}$ & $0.0229 \pm 0.0009^{\mathrm{c}}$ & $8.05 \pm 0.420^{\mathrm{c}}$ & $2.96 \pm 0.372^{\mathrm{b}}$ & $0.78 \pm 0.069^{\mathrm{b}}$ \\
\hline
\end{tabular}

$P_{\mathrm{N}}$ and TR values at the seven PAR settings i.e. $800,1000,1200,1400,1600,1800$ and $2000 \mu \mathrm{mol} \mathrm{m}^{-2} \mathrm{~s}^{-1}$ were used for comparing $P_{\mathrm{N}}$ and TR among species. Numbers in the table are means \pm SD. Same letters show no statistical difference among species by LSD test (Fisher) at $\alpha=0.05$. Correlation coefficients of $P_{\mathrm{N}}$ -AQY and $P_{\mathrm{N}}$-Biomass were 0.999* and 0.991*. 
(Figure 1(d); Figures 2(a), (d)). Here TR seemed to have a delayed response to the change of $L_{\mathrm{s}}$, but in fact TR was tightly linked to the increasing $T_{\mathrm{a}}$, PAR and vapor pressure deficit based on leaf temperature (VpdL), and decreasing RH (Correlation coefficients of TR with PAR, $T_{\mathrm{a}}, \mathrm{VpdL}$ and $\mathrm{RH}$ were derived as $0.89^{*}, 0.86^{*}$, $0.61 *$ and $-0.72 *$, respectively) (data not shown). This led to a high level of TR around noon even though at this time $g_{\mathrm{s}}$ decreased and/or $L_{\mathrm{s}}$ increased. Therefore, PAR, $T_{\mathrm{a}}$ and RH were the major drivers of TR (Figures 1(a), (b) and (d)), as VpdL negatively correlated with RH ( $\mathrm{r}=$ $-0.94 *)$ (data not shown).

The decrease of $C_{\mathrm{i}}$ is the major criterion for verifying $L_{\mathrm{s}}$ if $P_{\mathrm{N}}$ decreased or stayed at a low level [17]. In our experiment, $C_{\mathrm{i}}$ obviously decreased in the morning before $1100 \mathrm{~h}$ that reflected the normal changes from night (where $C_{\mathrm{i}}$ increased over time because of respiration) to daytime from increased intercellular $\mathrm{CO}_{2}$ use resulting from increasing photosynthesis. The decrease of $C_{\mathrm{i}}$ in $A$. rivularis from $1100 \mathrm{~h}$ until $1600 \mathrm{~h}$ (Figure 2(b)) was likely caused by the decrease of $g_{\mathrm{s}}$ (Figure 2(a)) since $P_{\mathrm{N}}$ decreased as well during this period (Figure 1(c)) and water stress was avoided by watering. Based on the above argument, the decrease of $P_{\mathrm{N}}$ from the late morning to the afternoon was mainly caused by a shortage of $\mathrm{CO}_{2}$ resulted from an increase of $L_{\mathrm{s}}$ and decrease of $g_{\mathrm{s}}$ (Figure 1(c); Figures 2(a), (d)). It is well known that the increase of $C_{\mathrm{i}}$ is the reason for non-stomatal limitation of photosynthesis when $P_{\mathrm{N}}$ is at a low level [18]. Therefore, the rapid decrease of $P_{\mathrm{N}}$ after $1700 \mathrm{~h}$ was caused by an increase of non-stomatal limitation (e.g., carboxylation resistance) that quite likely resulted from the decrease of PAR (Figure 1(a)), for even if $g_{\mathrm{s}}$ was at a low level, $C_{\mathrm{i}}$ increased and $L_{\mathrm{s}}$ decreased rapidly during this time. There is a strong correlation between $P_{\mathrm{N}}$ and $g_{\mathrm{s}}$ because stomata respond to the changes in assimilation via $C_{\mathrm{i}}$. Correlation analysis revealed a significantly positive correlation between $P_{\mathrm{N}}$ and $g_{\mathrm{s}}\left(\mathrm{r}=0.77^{*}\right)$, and a negative correlation between $P_{\mathrm{N}}$ and $C_{\mathrm{i}}\left(\mathrm{r}=-0.73^{*}\right)$ (data not shown).

When PAR was set to zero, the $P_{\mathrm{N}}$ values of $-2.5--2.0$ $\mu \mathrm{mol}\left(\mathrm{CO}_{2}\right) \mathrm{m}^{-2} \mathrm{~s}^{-1}$ might reflected the respiration rates of the Anemones under the experimental conditions (Figure 4).

\subsection{Response of Photosynthesis to Light Intensity}

In lettuce [19], tobacco [20], and Phaseolus vulgaris [21], $P_{\mathrm{N}}$ along with the increase of light intensity increased to a peak, then decreased if the light intensity increased further. However, in ramie (Boehmeria nivea (L.) Gaud.) [22], tomato [23], cucumber [17], and cotton [24], as light intensity increased, $P_{\mathrm{N}}$ increased and kept on at a high level within a wide range of light intensity. The depression of photosynthesis in tobacco when PAR $>600 \mu \mathrm{mol}$ $\mathrm{m}^{-2} \mathrm{~s}^{-1}$ was due to the reduction in activities of PSI and PSII, carbonic anhydrase and electron transfer speed [20]. A large decrease in stomatal conductance to water vapour in Phaseolus vulgaris leaves exposed to strong light was found [21].

In our experiments, strong light of no more than PAR $1800 \mu \mathrm{mol} \mathrm{m} \mathrm{m}^{-2} \mathrm{~s}^{-1}$ did not depress photosynthesis, although differences were observed in utilization of light energy under high light intensity (Figure 3(a)) with adequate soil water, $T_{\mathrm{a}} 23-30^{\circ} \mathrm{C}$ and $\mathrm{RH} 45-65 \%$. Furthermore, the sample leaf was put under a strong light for a few minutes for achieving a constant $P_{\mathrm{N}}$ before going to a lower PAR. Therefore, it needs more investigations to uncover whether or not the Anemone species have a photosystem insensitive to the change of light intensity. The experiment results, based on single leaf test, suggested that PAR $800-1000 \mu \mathrm{mol} \mathrm{m}^{-2} \mathrm{~s}^{-1}$ is enough for a satisfactory $P_{\mathrm{N}}$ and meets the needs for photosynthetic products for normal growth and development of Anemone cultivation.

Among the three species, A. rivularis was from a grass hillside under sparse trees with good sunshine and had a different response to light from other species, showing a high LCP and LSP. Whereas, A. hupehensis var. japonica was from a limestone wall with only intermittent sunshine and is probably less well adapted to continuous strong light. The light response data, low LCP and LSP, and low maximum $P_{\mathrm{N}}$ value all indicated that this species is the best one to grow under partial shade.

\subsection{Response of Photosynthesis to $\mathrm{CO}_{2}$}

Among $P_{\mathrm{N}}, \mathrm{TR}, g_{\mathrm{s}}$, and $C_{\mathrm{i}}$, only $P_{\mathrm{N}}$ and $C_{\mathrm{i}}$ were observed to increase regularly as $C_{\mathrm{a}}$ increased, and the response of $P_{\mathrm{N}}$ and $C_{\mathrm{i}}$ to the change of $C_{\mathrm{a}}$ showed little difference among the species (Figures 5(a), (b)). When $C_{\mathrm{a}}$ was set to zero, $P_{\mathrm{N}}$ was $-3 \mu \mathrm{mol}\left(\mathrm{CO}_{2}\right) \mathrm{m}^{-2} \mathrm{~s}^{-1}$ (Figure 5(a)) which was roughly considered as the sum of respiration and photorespiration under the experimental conditions. This was unlike the $P_{\mathrm{N}}$ values at $\mathrm{PAR}=0 \mu \mathrm{mol} \mathrm{m} \mathrm{m}^{-2} \mathrm{~s}^{-1}$ where the minus $P_{\mathrm{N}}$ values just presented the respiration rates. The $\mathrm{CO}_{2}$ saturation curve of photosynthesis in the considered species is still in need of study.

A higher CCP $\left(60-75 \mu \mathrm{mol}\left(\mathrm{CO}_{2}\right) \mathrm{mol}^{-1}\right)$, but a much lower LCP $\left(13-28 \mu \mathrm{mol} \mathrm{m} \mathrm{m}^{-2} \mathrm{~s}^{-1}\right)$, and similar diurnal curves of $P_{\mathrm{N}}$ and TR were observed in domesticated Primula species collected from an alpine area of north-western Yunnan Province, China [25]. This reflected the similarity in photosynthetic daily patterns of Anemones and Primulas as alpine plants, and the dissimilarity in light and $\mathrm{CO}_{2}$ utilization qualities of plants of the two genera, which should be taken into consideration for their cultivation. 


\section{Conclusions}

The Anemone species described here showed similar onepeak diurnal trends of $P_{\mathrm{N}}$, although A. rivularis had lower TR, $g_{\mathrm{s}}$, and $C_{\mathrm{i}}$, and higher $L_{\mathrm{s}}$ in the afternoon. Specific differences in response of $P_{\mathrm{N}}$ to PAR were observed, especially under strong light. A. rivularis had the highest $P_{\mathrm{N}}$ and $C_{\mathrm{i}}$ under strong light which corresponded with its high $g_{\mathrm{s}}$ and TR. A. rivularis had the highest LSP (1000 $\left.\mu \mathrm{mol} \mathrm{m} \mathrm{s}^{-1}\right)$ and LCP $\left(69 \mu \mathrm{mol} \mathrm{m} \mathrm{s}^{-2}\right)$, while A. hupehensis var. japonica had the lowest LSP $\left(800 \mu \mathrm{mol} \mathrm{m}^{-2}\right.$ $\left.\mathrm{s}^{-1}\right)$ and a lower LCP $\left(53 \mu \mathrm{mol} \mathrm{m} \mathrm{m}^{-2} \mathrm{~s}^{-1}\right)$. All these species responded similarly to the change of $C_{\mathrm{a}}$ from 0 to 350 $\mu \mathrm{mol}\left(\mathrm{CO}_{2}\right) \mathrm{mol}^{-1}$, and their $\mathrm{CCP}$ showed little difference. Moreover, A. rivularis had the highest AQY, CE, $P_{\mathrm{N}}$ and TR based on the $P_{\mathrm{N}}$ PAR response. In conclusion, $A$. rivularis is able to grow well under higher radiation, while $A$. hupehensis var. japonica is the best one to grow under partial shade.

\section{Acknowledgements}

The authors are grateful to the reading and comments given by Gordon Rowland, University of Saskatchewan. Thanks are expressed to Su WH of Yunnan University for his kind help in the equipment operation.

\section{REFERENCES}

[1] Y. L. Yuan, J. L. Zhao and W. P. XU, "Anemone of Morphology Characteristic and Introduction Apply Study," Acta Botanica Boreali-Occidentalia Sinica, Vol. 17, No. 5, 1997, pp. 134-136.

[2] Botanical Institute of Kunming CAoS, "Flora Yunnanica," Science Press, Beijing, Vol. 11, 2000, pp. 183-204.

[3] M. Y. Fang and M. Y. Yang, "A Study on Pollen Morphology and Evolution of the Genus Anemone from Sichuan," Journal of Sichuan University, Vol. 31, No. 2, 1994, pp. 246-258.

[4] Q. E. Yang, "Cytology of Ten Species in Anemone, One in Anemoclema and Six in Clematis (Trib. Anemoneae, Ranunculaceae) form China," Acta Phytotaxonomica Sinica, Vol. 40, No. 5, 2002, pp. 396-405.

[5] S. B. Hoot, "Phylogenetic Relationships in Anemone (Ranuculaceae) Based on Morphology and Chloroplast DNA," Systematic Botany, Vol. 19, No. 1, 1994, pp. 169-200.

[6] Y. Jacob, "Breeding of Anemone Coronaria Tetraploid Hybrids," Proceedings of the Seventh International Symposium on Flower Bulbs, Vol. II, Herzliya, Israel. Acta Horticulturae, Vol. 430, 1997, pp. 503-508.

[7] T. Lindell, "Breeding Systems and Crossing Experiments in Anemone Patens and in the Anemone Pulsatilla Group (Ranunculaceae)," Nordic Journal of Botany, Vol. 18, No. 5, 1998, pp. 549-561.

[8] J. J. Vacher, "Responses of Two Main Andean Crops, Quinoa (Chenopodium quinoa Willd) and Papa Amarga
(Solanum juzepczukii Buk.) to Drought on the Bolivian Altiplano: Significance of Local Adaptation," Agriculture, Ecosystems \& Environment, Vol. 68, No. 1-2, 1998, pp. 99-108.

[9] G. D. Farquhar and T. D. Sharkey, "Stomatal Conductance and Photosynthesis," Annual Review of Plant Physiology, Vol. 33, 1982, pp. 317-345.

[10] J. Ehleringer and O. Björkman, "Quantum Yields for $\mathrm{CO}_{2}$ Uptake in $\mathrm{C}_{3}$ and $\mathrm{C}_{4}$ Plants," Plant Physiology, Vol. 59, No. 1, 1977, pp. 86-90.

[11] J. Ehleringer and R. W. Pearcy, "Variation in Quantum Yield for $\mathrm{CO}_{2}$ Uptake among $\mathrm{C}_{3}$ and $\mathrm{C}_{4}$ Plants," Plant Physiology, Vol. 73, No. 3, 1983, pp. 555-559.

[12] Z. Y. Tao and Q. Zou, "Effect of Strong Irradiance and Shortly Elevated $\mathrm{CO}_{2}$ Concentrations on Photosynthetic Efficiencies in Maize and Soybean Leaves," Acta Botanica Boreali-Occidentalia Sinica, Vol. 25, No. 2, 2005, pp. 244-249.

[13] Z. J. Wang, T. C. Guo, Y. J. Zhu, Y. H. Wang, J. H. Wang and M. Zhao, "Comparison of $\mathrm{CO}_{2}$ Assimilation Capacity in Flag Leaf for Super High Yield Wheat with Different Spike Type," Acta Agronomica Sinica, Vol. 30, No. 8, 2004, pp. 739-744.

[14] S. Pandey, S. Kumar and P. K. Nagar, "Photosynthetic Performance of Ginkgo Biloba L. Grown under High and Low Irradiance," Photosynthetica, Vol. 41, No. 4, 2003, pp. 505- 511.

[15] R. V. Ribeiro, G. B. Lyra, A. V. Santiago, A. R. Pereira, E. C. Machado and R. F. Oliveira, "Diurnal and Seasonal Patterns of Leaf Gas Exchange in Bahiagrass (Paspalum Notatum Flugge) Growing in A Subtropical Climate," Grass and Forage Science, Vol. 61, No. 3, 2006, pp. 293 -303 .

[16] A. C. Tay, A. M. Abdullah, M. Awang and A. Furukawa, "Midday Depression of Photosynthesis in Enkleia Malaccensis, a Woody Climber in a Tropical Rainforest," Photosynthetica, Vol. 45, No. 2, 2007, pp. 189-193.

[17] D. H. Ma, J. A. Pang, Z. R. He and S. J. Li, "Effect of Environmental Factors on the Photosynthetic Characteristics of Cucumber Seedlings," Acta Botanica Boreali-Occidentalia Sinica, Vol. 12, No. 4, 1997, pp. 97-100.

[18] D. Q. Xu, "Some Problems in Stomatal Limitation Analysis of Photosynthesis," Plant Physiology Communications, Vol. 33, No. 4, 1997, pp. 241-244.

[19] P. P. Li, Y. G. Hu, Y. G. Zhao, X. J. Ying and H. P. Mao, "Comprehensive Model on the Effect of $\mathrm{CO}_{2}$ Enrichment on Lettuce Photosynthesis in Greenhouse," Transaction of the CSAE, Vol. 17, No. 3, 2001, pp. 75-79.

[20] L. Jiang, S. Q. Cao, X. Dai and X. M. Xu, "Effect of Different Light Intensity on Photosynthesis of Tobacco," Journal of Chinese Tobacco, Vol. 6, No. 4, 2000, pp. 17-20.

[21] L. Guidi, M. Tonini and G. F. Soldatini, "Effects of High Light and Ozone Fumigation on Photosynthesis in Phaseolus Vulgaris," Plant Physiology and Biochemistry, Vol. 38, No. 9, 2000, pp. 717-725. 
[22] Q. Q. Guo, "Study on the Photosynthetic Characteristics of Ramie Leaves in Different Varieties and Their Relationship with Yield Formation of Ramie. II. The PhysiolEcological Characteristics of Leaf in Photosynthesis," Journal of Hunan Agricultural College, Vol. 17, No. 3, 1993, pp. 76-79.

[23] C. Stanghellini and J. A. Bunce, "Response of Photosynthesis and Conductance to Light, $\mathrm{CO}_{2}$, Temperature and Humidity in Tomato Plants Acclimated to Ambient and
Elevated $\mathrm{CO}_{2}$," Photosynthetica, Vol. 29, 1993, pp. 487 $-497$.

[24] H. Z. Dong, W. J. Li, W. Tang and Z. H. Li, "Photosynthetic Characteristics of Field Grown Cotton Leaves," Shangdong Agricultural Science, No. 6, 2000, pp. 7-10.

[25] F. H. Liu, S. M. Hou and X. N. Liang, "Gas Exchange Characteristics of Four Domesticated Primula Species," New Zealand Journal of Crop and Horticultural Science, Vol. 34, 2006, pp. 403-411. 